\title{
Photobiomodulation with Red and Near-Infrared Light Improves Viability and Modulates Expression of Mesenchymal and Apoptotic-Related Markers in Human Gingival Fibroblasts
}

\author{
Ievgeniia Kocherova ${ }^{1,2}\left(\mathbb{D}\right.$, Artur Bryja ${ }^{1}\left(\mathbb{D}\right.$, Katarzyna Błochowiak $^{3}$, Mariusz Kaczmarek ${ }^{4,5}(\mathbb{D}$, \\ Katarzyna Stefańska ${ }^{6}{ }^{\oplus}$, Jacek Matys ${ }^{7}{ }^{\oplus}$, Kinga Grzech-Leśniak ${ }^{7,8}$, Marzena Dominiak ${ }^{7}{ }^{\circledR}$, Paul Mozdziak ${ }^{9,10}{ }^{\oplus}$, \\ Bartosz Kempisty 1,6,10,11 and Marta Dyszkiewicz-Konwińska ${ }^{1,12, *}$
}

1 Department of Anatomy, Poznan University of Medical Sciences, 60-781 Poznań, Poland; kocherova.evgenia@gmail.com (I.K.); abryja@ump.edu.pl (A.B.); bkempisty@ump.edu.pl (B.K.)

2 Department of Rheumatology, Center of Experimental Rheumatology, University Hospital Zurich, University of Zurich, 8952 Schlieren, Switzerland

3 Department of Oral Surgery and Periodontology, Poznan University of Medical Sciences, 61-812 Poznań, Poland; kasia@naszdentysta.com.pl

4 Department of Cancer Immunology, Chair of Medical Biotechnology, Poznan University of Medical Sciences, 61-866 Poznań, Poland; markacz@ump.edu.pl

check for updates

Citation: Kocherova, I.; Bryja, A.; Błochowiak, K.; Kaczmarek, M.; Stefańska, K.; Matys, J.;

Grzech-Leśniak, K.; Dominiak, M.; Mozdziak, P.; Kempisty, B.; et al. Photobiomodulation with Red and Near-Infrared Light Improves Viability and Modulates Expression of Mesenchymal and Apoptotic-Related Markers in Human Gingival Fibroblasts. Materials 2021, 14, 3427. https:// doi.org/10.3390/ma14123427

Academic Editor: Irina Paun

Received: 23 April 2021

Accepted: 17 June 2021

Published: 21 June 2021

Publisher's Note: MDPI stays neutral with regard to jurisdictional claims in published maps and institutional affiliations.

Copyright: (c) 2021 by the authors. Licensee MDPI, Basel, Switzerland. This article is an open access article distributed under the terms and conditions of the Creative Commons Attribution (CC BY) license (https:// creativecommons.org/licenses/by/ $4.0 /)$.
5 Gene Therapy Laboratory, Department of Cancer Diagnostics and Immunology, Greater Poland Cancer Centre, 61-866 Poznań, Poland

6 Department of Histology and Embryology, Poznan University of Medical Sciences, 60-781 Poznań, Poland; k.stefanska94@o2.pl

7 Laser Laboratory at Dental Surgery Department, Medical University of Wroclaw, 50-425 Wrocław, Poland; jacek.matys@wp.pl (J.M.); kg@periocare.pl (K.G.-L.); marzena.dominiak@umed.wroc.pl (M.D.)

8 Department of Periodontics, School of Dentistry Virginia Commonwealth University, VCU, Richmond, VA 23298, USA

9 Physiology Graduate Program, North Carolina State University, Raleigh, NC 27695, USA; pemozdzi@ncsu.edu

10 Prestage Department of Poultry Science, North Carolina State University, Raleigh, NC 27695, USA

11 Department of Veterinary Surgery, Institute of Veterinary Medicine, Nicolaus Copernicus University in Torun, 87-100 Toruń, Poland

12 Department of Biomaterials and Experimental Dentistry, Poznan University of Medical Sciences, 60-812 Poznań, Poland

* Correspondence: mdyszkiewicz@ump.edu.pl; Tel.: +48-61-8547067

Abstract: Photobiomodulation (PBM), also called low-level laser treatment (LLLT), has been considered a promising tool in periodontal treatment due to its anti-inflammatory and wound healing properties. However, photobiomodulation's effectiveness depends on a combination of parameters, such as energy density, the duration and frequency of the irradiation sessions, and wavelength, which has been shown to play a key role in laser-tissue interaction. The objective of the study was to compare the in vitro effects of two different wavelengths $-635 \mathrm{~nm}$ and $808 \mathrm{~nm}$ - on the human primary gingival fibroblasts in terms of viability, oxidative stress, inflammation markers, and specific gene expression during the four treatment sessions at power and energy density widely used in dental practice $\left(100 \mathrm{~mW}, 4 \mathrm{~J} / \mathrm{cm}^{2}\right)$. PBM with both 635 and $808 \mathrm{~nm}$ at $4 \mathrm{~J} / \mathrm{cm}^{2}$ increased the cell number, modulated extracellular oxidative stress and inflammation markers and decreased the susceptibility of human primary gingival fibroblasts to apoptosis through the downregulation of apoptotic-related genes (P53, CASP9, BAX). Moreover, modulation of mesenchymal markers expression (CD90, CD105) can reflect the possible changes in the differentiation status of irradiated fibroblasts. The most pronounced results were observed following the third irradiation session. They should be considered for the possible optimization of existing low-level laser irradiation protocols used in periodontal therapies.

Keywords: low-level laser treatment; LLLT; photobiomodulation; PBM; human gingival fibroblasts; in vitro 


\section{Introduction}

Since the first successful implementation of lasers in the mid-1960 for retina coagulation, lasers quickly have found their application in other fields of medicine, including dentistry [1]. In 1964, after high-energy lasers proved their effectiveness for bone ablation or osteotomy, Goldman et al. described the beneficial effects of the laser beam for dental caries treatment $[2,3]$. While high-energy lasers appeared to be a promising tool for hard tissue treatment, photobiomodulation (PBM), also called soft laser therapy or low-level laser irradiation (LLLI), may represent a treatment of choice for soft tissues. Low-level lasers cover a spectrum of red and near-infrared light (600-1100 nm), characterized by low absorption in water and the ability to penetrate biological tissues in a depth of $3 \mathrm{~mm}-15 \mathrm{~mm}[1,4]$.

Photobiomodulation has been used in periodontal treatment to stimulate repair and reduce pain and inflammation [5-8]. Application of PBM along with gingivectomy results in improved condition and faster regeneration [9]. In a study on wound healing after gingivectomy and gingivoplasty surgeries, low-level laser therapy application resulted in increased epithelialization and wound healing [10]. Laser irradiation was shown to be effective as an adjunctive treatment in promoting revascularization and pain control during the early healing of free gingival graft $[10,11]$. Moreover, LLLT was reported to exert a therapeutic effect in the nonsurgical treatment of chronic periodontitis $[1,12,13]$. Scaling and root planning combined with LLLT managed to improve radiographic bone density and to probe pocket depth short-term reduction in patients with chronic periodontitis [12].

The photobiomodulation effects on cells and periodontal tissues imply several complex mechanisms. Red and near-infrared light is primarily absorbed by cytochrome $c$ oxidase in the respiratory chain of the mitochondria membrane. Following the cascade of reactions, cell signaling and messenger molecules are upregulated due to increased mitochondrial activity, including reactive oxygen species (ROS) and adenosine triphosphate (ATP) synthesis. The application of near-infrared light $(810-1064 \mathrm{~nm})$ stimulates lightsensitive ion channels increasing the levels of calcium ions $\left(\mathrm{Ca}^{2+}\right)$ and its interaction with ROS and cyclic AMP (cAMP). All of these activities stimulate cell proliferation, migration and differentiation [7].

Additionally, near-infrared light has been suggested to increase the activity in the cell plasma membrane [14]. Low biochemical activity has been observed in wavelengths in the range of 700-770 nm. The optimum wavelength for near-infrared irradiation of biological tissues is usually considered to be around $810 \mathrm{~nm}$ [15]. However, some clinical trials have speculated that 630 to $660 \mathrm{~nm}$ may be the most effective wavelength to bring desirable effects on cells and tissues [16].

Notably, the effectiveness of photobiomodulation on the target tissues is dependent on a combination of parameters such as wavelength, energy density, the duration and frequency of the laser application [17]. The wavelength plays a key role in laser-tissue interaction, modulating the absorption and scattering characteristics [4,17]. Meanwhile, a biphasic dose-response affects the PBM clinical outcomes, indicating a therapeutic window for the optimal therapeutic reaction [18]. Despite the considerable efforts of accumulating in vitro and in vivo studies, the exact parameters remain controversial [12,19-22]. Substantial heterogeneity has been reported in the laser parameters and regimens among the different studies, with wavelengths ranging from $630 \mathrm{~nm}$ to $830 \mathrm{~nm}$, output powers between 0.2 and $250 \mathrm{~mW}$, and application frequencies ranging from 4 to 10 treatments [23]. The dose-dependent effects of PBM can be described by Arndt-Schultz's curve, suggesting that the weak stimuli have the potential to enhance the physiological activity of treated cells and tissues. However in case of moderate stimuli, the activity is decreased, and extreme stimulation restrains and eliminates the activity [24,25] underlying the crucial role of the appropriate dosage for laser therapies. It has been revealed that the energy density ranging between $1-5 \mathrm{~J} / \mathrm{cm}^{2}$ is optimal to achieve an optimal biological effect in different cells and organs, including periodontal tissues [23,24,26,27]. In addition to being used in various studies on different wavelengths, the doses falling within the range 
of $2-4 \mathrm{~J} / \mathrm{cm}^{2}$ are mentioned in the World Association for Photobiomodulation Therapy (WALT) recommendations LLLT application in different fields of medicine [28].

The present study aimed to compare the in vitro effects of two different wavelengths. This included $635 \mathrm{~nm}$ and $808 \mathrm{~nm}$ on the human gingival fibroblasts in terms of viability, oxidative stress markers and specific genes expression during the four treatment sessions at power and energy density widely used in dental practice $\left(100 \mathrm{~mW}, 4 \mathrm{~J} / \mathrm{cm}^{2}\right)$.

\section{Materials and Methods}

\subsection{Cell Isolation}

Human primary gingival fibroblasts were obtained from healthy gingival tissues of 12 patients ( 6 males, 6 females, age range 25-48 years old) undergoing impacted tooth extraction. The patients involved in the study had no systemic and metabolic diseases and did not receive any periodontal therapy within the last year. The patients with aggressive or generalized periodontitis, intraoral lesions, and smokers were excluded from the study. All patients meeting the criteria gave informed written consent to participate in the study.

Each gingival fragment was placed in a sterile $15 \mathrm{~mL}$ Falcon tube containing $5 \mathrm{~mL}$ of Dulbecco's modified Eagle's medium (DMEM, Sigma-Aldrich; Merck KGaA, Darmstadt, Germany). It was supplemented with $1 \%$ antibiotic/antimycotic solutions (Gibco; Thermo Fisher Scientific, Inc., Waltham, MA, USA) and transported to the laboratory for further cell isolation. Next, the samples were cut into small pieces and digested with collagenase type I $(1 \mathrm{mg} / \mathrm{mL})$ and Dispase II $(1 \mathrm{mg} / \mathrm{mL}$, both from Gibco; Thermo Fisher Scientific, Inc., Waltham, MA, USA) at $37^{\circ} \mathrm{C}$ overnight.

The enzyme solution containing cells and tissue debris was centrifuged at $300 \times g$ for $8 \mathrm{~min}$. The cellular pellet was resuspended in fresh DMEM supplemented with $10 \%$ fetal bovine serum (Sigma-Aldrich; Merck KGaA, Darmstadt, Germany), 4 mM L-glutamine (stock 200 mM; Gibco; Thermo Fisher Scientific, Inc., Waltham, MA, USA), 10 mg/mL gentamicin (Gibco; Thermo Fisher Scientific, Inc., Waltham, MA, USA), 10,000 U/mL penicillin and 10,000 $\mathrm{\mu g} / \mathrm{mL}$ streptomycin (Gibco; Thermo Fisher Scientific, Inc., Waltham, MA, USA). Then it was transferred to T25 cell culture flasks and cultured at $37^{\circ} \mathrm{C}$ in a humid $5 \% \mathrm{CO}_{2}$ atmosphere. The culture medium was changed every $48 \mathrm{~h}$ until $80-90 \%$ confluence was reached. Cells were sub cultured using 0.25\% trypsin-EDTA solution (Sigma-Aldrich; Merck KGaA, Darmstadt, Germany). The cells were propagated and passaged three times before the experiment (Figure 1).

\subsection{Phenotypic Characterization}

The mesenchymal character of isolated gingival fibroblasts was confirmed by investigating the presence of the following surface markers: CD44, CD90, and CD105 with a FACScan flow cytometer (Becton Dickinson, San Jose, CA, USA). The following antibodies were used: CD44-PE (human, 130-113-897); CD90-FITC (human, clone: REA897, 130-114-901); CD105-APC (human, clone: REA794, 130-112-324) and REA Control (S)-PE (130-113-438), REA Control (S)-FITC (130-113-437), REA Control (S)-FITC (130-113-437), REA Control (S)-APC (130-113-434) and REA Control (S)-PE (130-113-438) from Miltenyi Biotec (Bergisch Gladbach, Germany). The data were analyzed using CellQuest Pro Software (Becton Dickinson, San Jose, CA, USA, version 5.2.1). 
A

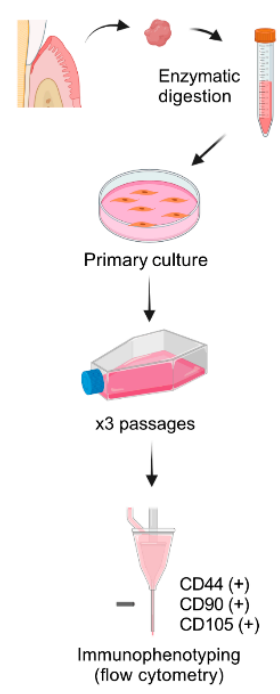

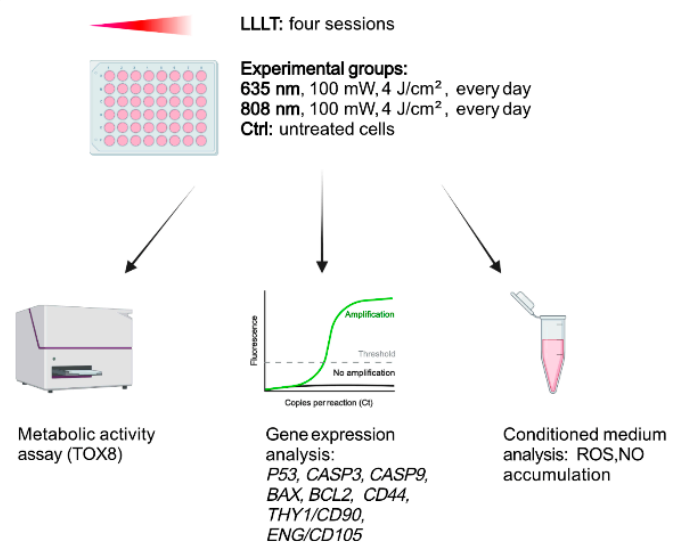

Figure 1. Schematic representation of the experimental design. (A) Gingival tissue samples were enzymatically digested to isolate the gingival fibroblasts for further primary in vitro culture. The cells were propagated and passaged three times and immunophenotyped before the experiment. (B) The cells were divided into control (untreated) and two experimental groups, which were subjected to LLLT sessions with red $(635 \mathrm{~nm})$ or near-infrared $(808 \mathrm{~nm})$ light. Following $24 \mathrm{~h}$ after each LLLT session, the metabolic activity assay was performed. The cells were harvested for gene expression analysis. The conditioned medium was collected to assess the level of extracellular oxidative stress and inflammation markers, created with BioRender.

\subsection{Laser Irradiation}

To examine the effects of low-level laser irradiation, the gingival fibroblasts at the third passage were seeded into 48 -well plates at the number of $5 \times 10^{3}$ cells per well. Empty wells separated the experimental wells seeded with the cells to avoid overlapping of scattered irradiation. After $24 \mathrm{~h}$, the culture medium was changed to remove the unattached cells. One group was treated with a diode laser emitting at the wavelength of $635 \mathrm{~nm}$, power $100 \mathrm{~mW}$ and energy density $4 \mathrm{~J} / \mathrm{cm}^{2}$. In contrast, another group was subjected to irradiation at $808 \mathrm{~nm}, 100 \mathrm{~mW}, 4 \mathrm{~J} / \mathrm{cm}^{2}$, (handpiece diameter: $8 \mathrm{~mm}$, spot area: $0.5024 \mathrm{~cm}^{2}$, average power density: $199.04 \mathrm{~mW} / \mathrm{cm}^{2}$, continuous mode, dose: $4 \mathrm{~J} / \mathrm{cm}^{2}$, time: $20 \mathrm{~s}$, the total energy dose after all sessions were $\left.16 \mathrm{~J} / \mathrm{cm}^{2}\right),($ Smart M, Lasotronix, Poland). The cells were irradiated every $24 \mathrm{~h}$ during the four days. The untreated cells served as a control with medium changed every $24 \mathrm{~h}$. Twenty four hours after each LLLI, we assessed the cell viability, selected genes expression, ROS and NO accumulation in the culture medium.

\subsection{Cell Viability Assay}

The number of viable cells in culture was estimated with TOX8 resazurin-based assay following the manufacturer's protocol (TOX8, In vitro Toxicology Assay Kit, Sigma-Aldrich; Merck KGaA, Darmstadt, Germany). Briefly, following $24 \mathrm{~h}$ after each photobiomodulation, the culture medium was replaced with a fresh one containing $10 \%$ of the TOX8 dye solution. The plates were placed in the incubator for the next $4 \mathrm{~h}$. Afterwards, $100 \mu \mathrm{L}$ of medium from each well was transferred into a 96-well plate. The absorbance level was measured at $600 \mathrm{~nm}$ and $690 \mathrm{~nm}$ (reference wavelength) using a Synergy 2 plate reader (BioTek, Winooski, VT, USA). The decrease in absorbance is proportional to the metabolic activity and, consequently, to the number of living cells.

Furthermore, the number of viable cells was estimated based on the growth curve calculated in parallel with the cytotoxicity test. The cells were seeded at the density of $2.5 \times 10^{3}, 5 \times 10^{3}, 7.5 \times 10^{3}$ and $10^{4}$ per well, and the level of dye absorbance was measured concerning the specific cells number to prepare the growth curve. The obtained linear trendline equation allowed us to estimate the number of cells. 


\subsection{Estimation of Extracellular Oxidative Stress and Inflammation Markers}

The conditioned culture medium was collected from the wells following $24 \mathrm{~h}$ after each PBM treatment. ROS concentration in the conditioned medium was assessed by incubation with 2', $7^{\prime}$-dichlorodihydrofluorescein diacetate solution (H2D-CF-DA, Invitrogen, Thermo Fisher Scientific, Inc., Waltham, MA, USA) for $30 \mathrm{~min}$ at $37^{\circ} \mathrm{C}$ and subsequent spectroscopic measurement at wavelengths of $495 \mathrm{~nm}$ and $529 \mathrm{~nm}$. Nitric oxide (NO) concentration was determined with the Griess Reagent Kit (Invitrogen, Thermo Fisher Scientific, Inc., Waltham, MA, USA). Each samples' absorbance was measured at $548 \mathrm{~nm}$ and converted to nitrite concentrations relative to the reference sample, following the manufacturer's instructions. All procedures were performed in triplicate. The Synergy 2 (BioTek, Winooski, VT, USA) multi-mode plate reader was used for spectroscopic measurements.

\subsection{Analysis of Chosen Genes Expression}

Gingival fibroblasts were collected following $24 \mathrm{~h}$ after each PBM treatment. The process of RNA isolation was performed according to the modified Chomczyński and Sacchi method $[29,30]$. Briefly, the cells were suspended in a monophase solution of guanidine thiocyanate and phenol (TRI Reagent ${ }^{\circledR}$, Sigma-Aldrich; Merck KGaA, Darmstadt, Germany). Next, the chloroform was added, with the samples centrifuged to obtain three separate phases. Total RNA located in the upper, aqueous phase was then precipitated with 2-propanol (Sigma-Aldrich; Merck KGaA, Darmstadt, Germany) and washed twice with $75 \%$ ethanol. Finally, RNA was dried and resuspended in $30 \mu \mathrm{L}$ of pure water. RNA quantity and purity were examined spectrophotometrically (Epoch, Biotek, Bad Friedrichshall, Germany). Samples with a 260/280 absorbance coefficient greater than 1.8 were used for further experiments. The reverse transcription reaction was conducted according to the protocol provided by the manufacturer-SA Biosciences (RT2 First Stand kit-330401). RT-qPCR was performed using LightCycler (Roche Diagnostics GmbH, Mannheim, Germany). The amplification process was carried out using a $2 \mu \mathrm{L}$ of cDNA solution, $18 \mu \mathrm{L}$ of QuantiTect ${ }^{\circledR}$ SYBR ${ }^{\circledR}$ Green PCR (Master Mix Qiagen GmbH, Hilden, Germany) and primers (Table 1).

Table 1. Sequences of primers used in RT-qPCR.

\begin{tabular}{|c|c|c|}
\hline Gene & Primer Sequence $\left(5^{\prime}-3^{\prime}\right)$ & Product Size (bp) \\
\hline P53 & $\begin{array}{l}\text { GCTGAATGAGGCCTTGGAAC } \\
\text { TTATGGCGGGAGGTAGACTG }\end{array}$ & 114 \\
\hline CASP3 & $\begin{array}{l}\text { ATGTCGATGCAGCAAACCTC } \\
\text { GCACACAAACAAAACTGCTCC }\end{array}$ & 150 \\
\hline CASP9 & $\begin{array}{l}\text { TGATGTCGGTGCTCTTGAGA } \\
\text { CGCAACTTCTCACAGTCGAT }\end{array}$ & 162 \\
\hline$B A X$ & $\begin{array}{l}\text { TGACATGTTTTCTGACGGCA } \\
\text { CACCCTGGTCTTGGATCCA }\end{array}$ & 179 \\
\hline BCL2 & $\begin{array}{l}\text { ATGTGTGTGGAGAGCGTCAA } \\
\text { GAAATCAAACAGAGGCCGCA }\end{array}$ & 168 \\
\hline$C D 44$ & $\begin{array}{l}\text { TCTGTGCAGCAAACAACACA } \\
\text { TAGGGTTGCTGGGGTAGATG }\end{array}$ & 234 \\
\hline THY1/CD90 & $\begin{array}{l}\text { CTAGTGGACCAGAGCCTTCG } \\
\text { TGGAGTGCACACGTGTAGGT }\end{array}$ & 236 \\
\hline ENG/CD105 & $\begin{array}{l}\text { CACTAGCCAGGTCTCGAAGG } \\
\text { CTGAGGACCAGAAGCACCTC }\end{array}$ & 165 \\
\hline$A C T B$ & $\begin{array}{l}\text { AAAGACCTGTACGCCAACAC } \\
\text { CTCAGGAGGAGCAATGATCTTG }\end{array}$ & 132 \\
\hline GAPDH & $\begin{array}{l}\text { TCAGCCGCATCTTCTTTTGC } \\
\text { ACGACCAAATCCGTTGACTC }\end{array}$ & 90 \\
\hline
\end{tabular}

Relative gene expression was obtained using the $2^{-\Delta \Delta \mathrm{Ct}}$ method [31]. The geometric mean of CT of $\beta$-actin (ACTB) and glyceraldehyde 3-phosphate dehydrogenase (GAPDH) was used as the reference. 


\subsection{Analysis of Chosen Genes Expression}

Statistical analysis was carried out using GraphPad Prism 8 software (San Diego, CA, USA, version 8.0.1.244).

The Shapiro-Wilk test was used to verify the normality of the data distribution. Oneway analysis of variance (ANOVA) with Tukey's post hoc test was applied for multiple comparisons between the studied groups. The results are presented as mean \pm standard deviation (SD), and $p<0.05$ was considered statistically significant.

\section{Results}

The cells isolated from the gingival tissue samples presented the surface antigens typical for mesenchymal lineage cells, i.e., expression of CD44, CD90, and CD105 markers (Figure 2).
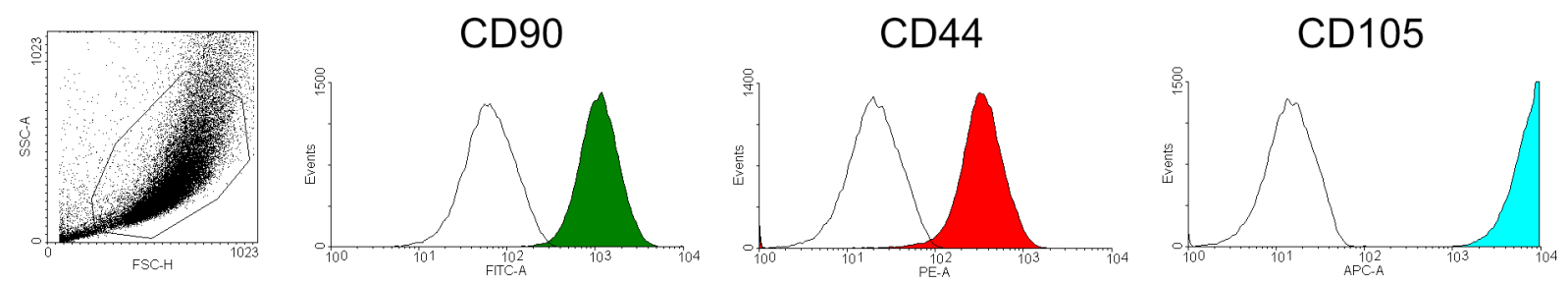

Figure 2. Phenotypical characterization of human primary gingival fibroblasts. Isolated cells were positive for $C D 44, C D 90$, and CD105.

The resazurin-based assay (TOX8) revealed that photobiomodulation positively affected the cell number in gingival fibroblast cultures (Figure 3). The treatment with a $635 \mathrm{~nm}$ laser resulted in significant cell numbers $24 \mathrm{~h}$ after the first PBM (D1) compared to the control group. Instead, the second treatment (D2) did not influence the number of cells in the case of both $635 \mathrm{~nm}$ and $808 \mathrm{~nm}$ wavelengths. In contrast, the third PBM significantly improved this parameter in treated groups compared to control (D3). However, $24 \mathrm{~h}$ after the fourth PBM (D4), there was no significant difference between the irradiated and non-treated cells.
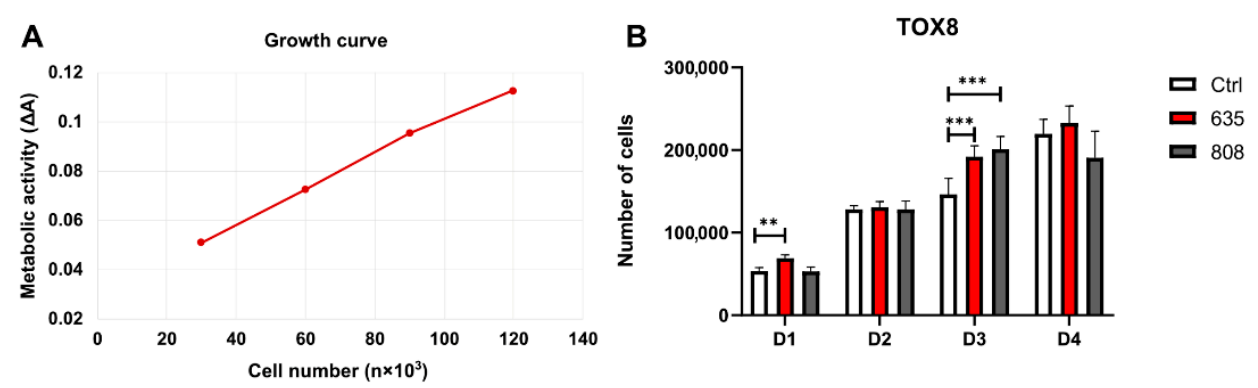

Figure 3. (A) The growth curve is showing the level of metabolic activity normalized to cell number. (B) Mean cells number in the irradiated and non-treated groups assessed with TOX8 metabolic activity assay. Results expressed as mean $\pm \mathrm{SD}{ }^{* *} p<0.01,{ }^{* * *} p<0.001$.

The conditioned medium was collected $24 \mathrm{~h}$ after every PBM treatment to assess the effects of photobiomodulation on the accumulation of molecular markers associated with oxidative stress and inflammation into the extracellular environment (Figure 4). After the second irradiation (D2), there was a significantly higher concentration of ROS in the medium collected from wells irradiated with $808 \mathrm{~nm}$ when compared to the $635 \mathrm{~nm}$ wavelength. Noticeably, the highest statistically significant differences were obtained after the third exposure to laser irradiation (D3). There was a significantly higher ROS accumulation in the conditioned medium of the gingival fibroblasts treated with $635 \mathrm{~nm}$ and $808 \mathrm{~nm}$ diode laser compared to the medium collected from the control group. After the fourth irradiation (D4), the differences between the experimental groups were not 
statistically significant. Interestingly, the ROS levels decreased considerably in all three groups when compared to earlier time points (D4).
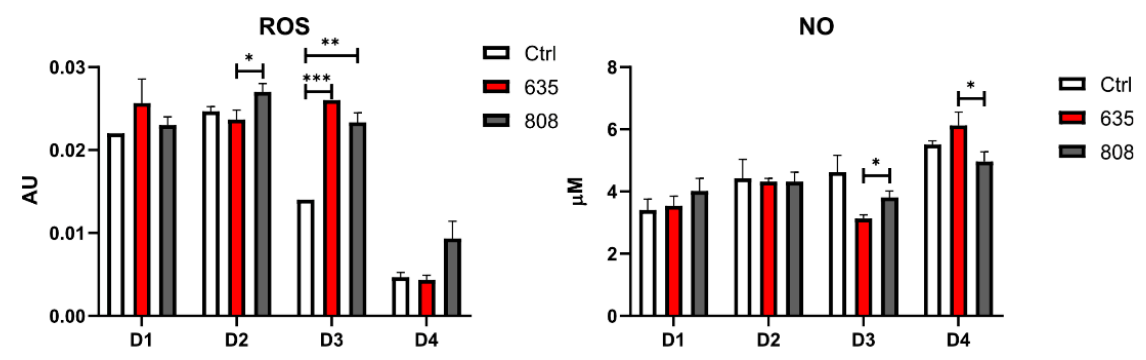

Figure 4. The levels of extracellular oxidative stress and inflammation markers in cultured human gingival fibroblasts. Results expressed as mean \pm SD. ${ }^{*} p<0.05,{ }^{* *} p<0.01,{ }^{* * *} p<0.001$.

No difference was noted in extracellular NO concentrations between the groups following the first two PBM treatments (D1, D2). The level of NO decreased significantly after the third exposure to $635 \mathrm{~nm}$ wavelength compared to $808 \mathrm{~nm}$ (D3). Interestingly, the fourth treatment revealed the opposite effect- NO concentrations rose significantly in wells exposed to $635 \mathrm{~nm}$ than $808 \mathrm{~nm}$. Additionally, in contrast to ROS accumulation dynamics, there was a significant increase in NO concentrations following the fourth PBM (D4) compared to the third laser treatment (D3).

The RT-qPCR method demonstrated a significant decrease in pro-apoptotic P53 and CASP9 gene expression following the third (D3) exposure to $635 \mathrm{~nm}$ and $808 \mathrm{~nm}$ diode laser (Figure 5). The expression of CASP3 remained unchanged in all groups. The downregulation of $B A X$ was observed following the third exposure to $635 \mathrm{~nm}$ wavelength only (D3). After the fourth laser treatment, the expression of anti-apoptotic BCL2 was significantly higher in cells subjected to the $808 \mathrm{~nm}$ wavelength compared to $635 \mathrm{~nm}$.
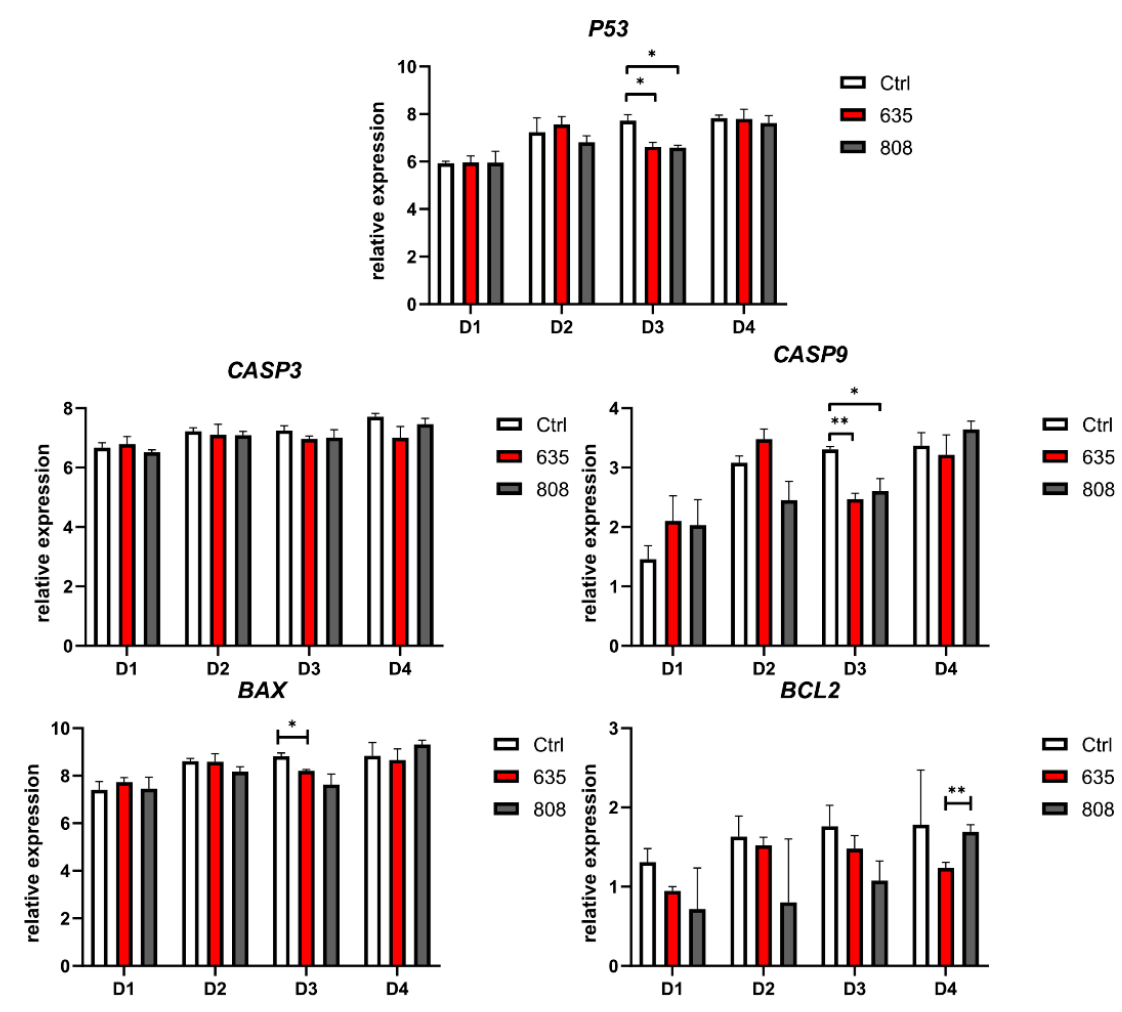

Figure 5. Expression of genes involved in apoptotic pathways in cultured human gingival fibroblasts. Results expressed as mean $\pm \mathrm{SD}, \mathrm{n}=12 .{ }^{*} p<0.05,{ }^{* *} p<0.01$. 
RT-qPCR evaluation of $C D 44, C D 90$, and $C D 105$ gene expression demonstrated that PBM did not significantly affect the CD44 mesenchymal gene expression (Figure 6). In contrast, the first stimulation with $808 \mathrm{~nm}$ upregulated the mesenchymal gene expression of both CD90 and CD105 genes (D1). Following the second PBM (D2), a significant CD90 downregulation in the group exposed to $808 \mathrm{~nm}$ irradiation compared to the control. The observed decrease in CD105 gene expression was not statistically significant. The third exposure resulted in significant $C D 90$ and CD105 downregulation in the case of both wavelengths (D3). Following the fourth PBM with $635 \mathrm{~nm}$, CD90 expression remained significantly downregulated.

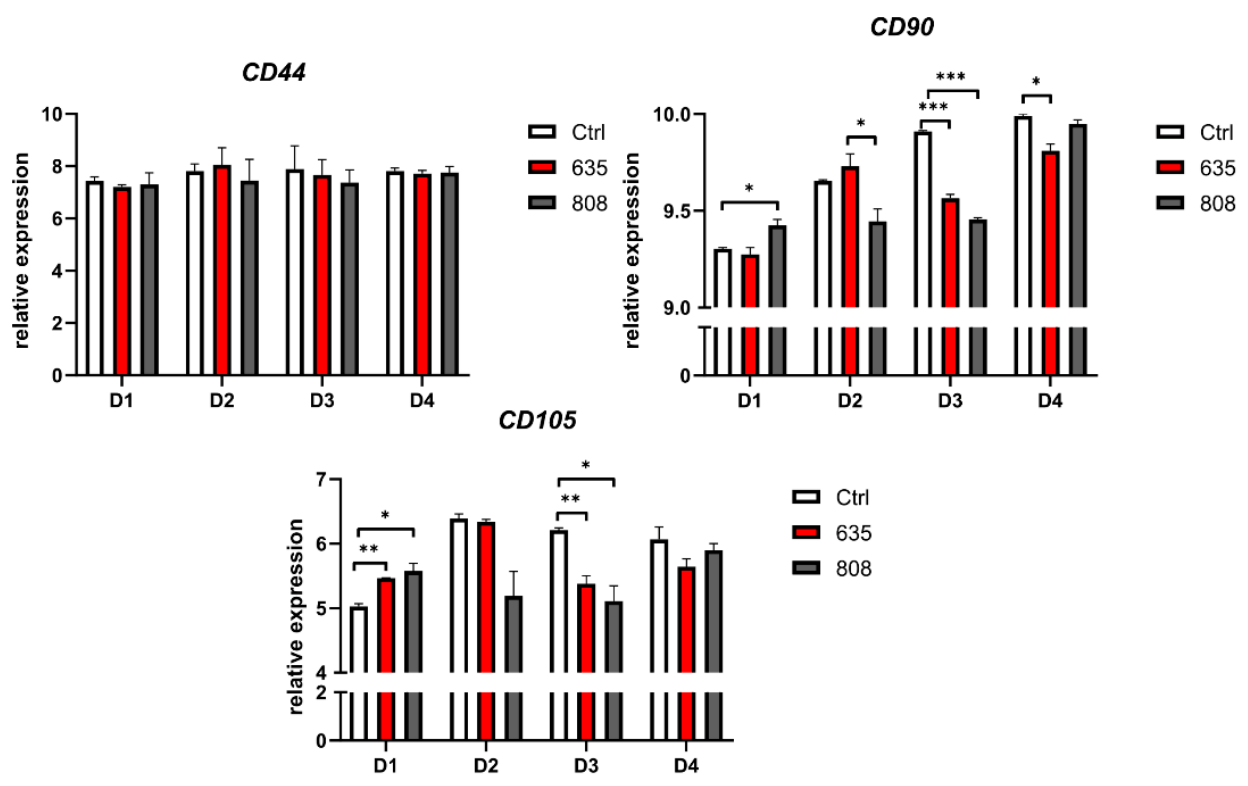

Figure 6. Gene expression of markers characteristic for mesenchymal stem cells in cultured human gingival fibroblasts. Results expressed as mean $\pm \mathrm{SD}, \mathrm{n}=12 .{ }^{*} p<0.05,{ }^{* *} p<0.01,{ }^{* * *} p<0.001$.

\section{Discussion}

The gingival tissue is composed of the superficial oral epithelium and underlying connective tissue. These tissues represent the first sites affected by interaction with biofilms and develop an inflammatory response. The gingival tissue is considered to be the initial location for destructive periodontal diseases [32].

As the main cells forming the connective tissue, fibroblasts are responsible for the extracellular matrix formation and maintaining the normal gingival tissue homeostasis. In the case of chronic pathological stimuli leading to connective tissue damage or managing loss of the gingival tissue, supplementing periodontal fibroblasts by grafting or stimulating cell migration, proliferation and viability seem to be a reasonable approach [33].

It has been documented that all these cell characteristics can be improved using photobiomodulation [34]. Almeida-Lopez et al. suggested enhanced human gingival fibroblasts proliferation in vitro following irradiation with diode laser at 670, 780, 692, or $782 \mathrm{~nm}$ and $2.0 \mathrm{~J} / \mathrm{cm}^{2}$ [27]. It was noted that shorter exposure resulted in higher proliferation. Frozanfar et al. observed a significant increase in gingival fibroblasts (HGF3PI53) proliferation on days 2 and 3 following the irradiation with $810 \mathrm{~nm}$ and $4.0 \mathrm{~J} / \mathrm{cm}^{2}$ [35]. Additionally, day three was marked by the dramatically increased expression of the collagen type 1 gene in cultured cells. Periera et al. described 3- to 6-fold higher NIH-3T3 fibroblasts number following the treatment with $904 \mathrm{~nm}$ diode laser at 3.0 and $4.0 \mathrm{~J} / \mathrm{cm}^{2}$ [36]. However, this effect was restricted to a small range of energy densities since the exposure to $5.0 \mathrm{~J} / \mathrm{cm}^{2}$ had no significant effect on fibroblast growth.

Increased proliferation and improved viability in gingival fibroblasts were confirmed by deregulation of apoptosis-related gene expression [33,34,37-42]. The assessment of cell 
viability is important in studies on PBM effects. Photobiomodulation stimulates mitochondria by affecting their respiratory chain components, resulting in cAMP, ATP, and ROS production, directly influencing cell proliferation by initiating the intracellular signaling cascades [43]. The proliferation of cells may explain the steady growth of cell number between D1 and D3 in each group after the seeding. However, $635 \mathrm{~nm}$ wavelength seemed to induce the proliferation at the earlier time (D1) and stimulated its significant growth after the third irradiation session (D3). At D4, the difference between the irradiated and control cells was not significant, which underlines the importance of an appropriate dose and session number correction. PBM therapies should be adjusted to induce proliferation but avoid overstimulation which could have a cytotoxic effect because of excessive free radicals production [44]. The highest cell number was observed following the third application of both 635 and $808 \mathrm{~nm}$ PBM, corresponding to the significantly higher ROS accumulation in the culture medium at D3. By contrast, George et al. observed the lower ROS generated using $636 \mathrm{~nm}$ laser than the non-irradiated cells. The $825 \mathrm{~nm}$ laser, instead, provoked a significant increase in the level of ROS compared to the control [16]. Interestingly, the authors tested different laser irradiation parameters and concluded that the ROS production within biological systems is more dependent on the wavelength of the laser rather than energy density.

Treatment with $635 \mathrm{~nm}$ and $808 \mathrm{~nm}$ revealed similar effects in most assays. The physiologic and pathologic role of ROS in periodontitis has been studied for years. Studies suggest that although low ROS levels can be beneficial, excessive concentration of ROS can result in the initiation and exacerbation of periodontitis. There is still not enough data explaining crosstalk between ROS and autophagy in periodontal disease. However, data are suggesting that ROS may play a crucial role in determining cell fate by inducing autophagy or apoptosis [45].

Significant differences between the wavelength effects were observed in the case of extracellular NO concentration. The third irradiation session (D3) resulted in a significant decrease in NO level in the group treated with $635 \mathrm{~nm}$, compared to $808 \mathrm{~nm}$. In contrast, there was an increase in NO following the fourth treatment (D4). NO may represent one of the by-products of PBM mediating the cellular effects of the therapy [46]. Moreover, Karu et al. reported the irradiation-controlled mitochondrial NO signaling pathway in cultured cells [47]. In contrast, PBM has been shown to reduce inflammation, including NO synthesis $[43,48-50]$. However, the present data revealed no significant difference between the irradiated and non-treated cells.

In addition to cell viability, oxidative stress, and inflammation, the present study assessed the dynamics of mesenchymal marker expression in irradiated primary gingival fibroblasts. Several previous studies have shown fibroblasts share a mesenchymal stem cell phenotype, including the similar expression pattern of antigens characteristic for the mesenchymal stem cells (MSCs) and multilineage differentiation potential [51-55]. Surface immunophenotyping by flow cytometry confirmed CD44, CD90, CD105 markers before the experiment. Next, the appropriate gene mRNA level was evaluated $24 \mathrm{~h}$ after each irradiation session to investigate the possible effect of PBM on mesenchymal-like features of the gingival fibroblasts. While the expression of $C D 44$ remained unchanged during the whole experiment, $C D 90$ and CD105 were significantly modulated by laser treatment, with the most pronounced changes following the third exposure (D3). CD90, also known as Thy-1, is typically referred to as a mesenchymal marker associated with fibroblasts [56]. CD90 was shown to control MSCs differentiation by acting as an obstacle in the pathway of differentiation commitment [57]. In fibroblasts, the existence of correlations between CD90 expression and particular cell function was presumed. For example, in the study of Liu et al., fibroblasts revealed the heterogeneous CD90 expression in lung fibroblasts [58]. Cells expressing CD90 were more susceptible to apoptosis than cells lacking its expression. The authors showed that $C D 90$ expression is associated with decreased levels of anti-apoptotic molecules Bcl-2 and Bcl-xL and upregulation of cleaved caspase-9. The present study revealed that $C D 90$ downregulation at $\mathrm{D} 3$ was accompanied by the significant decrease in 
pro-apoptotic $B A X$ expression following $635 \mathrm{~nm}$ laser irradiation suggesting a correlation between $C D 90$ and apoptosis-related factors expression.

Decreased CD90 levels may reflect the differentiation of cultured fibroblasts. For example, Mokoena et al. reported that PBM at $660 \mathrm{~nm}$ with $5 \mathrm{~J} / \mathrm{cm}^{2}$ successfully stimulated the human skin fibroblast differentiation into myofibroblasts [59]. Following 24,48 , and $72 \mathrm{~h}$, the authors observed a significant increase in cell viability in the treated fibroblasts accompanied by decreased Thy-1 (CD90) expression and modulation of differentiationrelated gene expression.

Interestingly, in the case of endoglin (CD105), the initial significant upregulation of gene expression followed the first treatment (D1). The third photobiomodulation resulted in the downregulation, similar to CD90. Endoglin, or CD105, is a type III coreceptor for TGF- $\beta 1$, and its overexpression in fibroblasts was reported to affect physiological Smad/Alk1/Alk5 signaling to suppress the synthesis of TGF- $\beta 1$ and extracellular matrix (ECM) proteins [60]. Endoglin may induce fibrosis development in different tissues, and its expression is higher in fibroblasts from fibrotic tissue than in non-fibrotic tissue [61]. CD90 and CD105 are overexpressed in carcinoma-associated fibroblasts [62]. PBM may modulate the differentiation status of cultured gingival fibroblasts, which agrees with recent studies describing that laser treatment may affect cell differentiation in human gingival fibroblasts, periodontal ligament cells, and stem cells $[49,63,64]$. The present study represents the first evidence of mesenchymal markers expression modulation in response to PBM in human primary gingival fibroblasts, which in part can explain the LLLI effects on cell differentiation reported in previous studies.

In conclusion, the present study revealed that PBM with 635 and $808 \mathrm{~nm}$ at $4 \mathrm{~J} / \mathrm{cm}^{2}$ increased the cell proliferation, modulated extracellular oxidative stress and inflammation markers, and decreased the susceptibility of human primary gingival fibroblasts to apoptosis through the downregulation of apoptosis-related genes. Moreover, the data indicate that the modulation of CD90 and CD105 mesenchymal markers expression can reflect the possible changes in differentiation status of irradiated fibroblasts. The laser irradiation parameters used in the present in vitro study proved safe and exerted several beneficial effects on treated cells from healthy donors. However, further studies should consider the effectiveness of their application in the gingival tissues affected by pathological changes to elucidate the possible differences in biological response and, finally, to adjust the periodontal treatment protocols.

Author Contributions: Conceptualization, I.K. and A.B.; methodology, J.M. and K.G.-L.; software, M.K.; validation, I.K., A.B. and P.M.; formal analysis, I.K., A.B. and K.S.; investigation, I.K., A.B. and K.G.-L.; resources, K.B.; data curation, K.B.; writing-original draft preparation, I.K. and A.B.; writing-review and editing, M.D.-K., M.D., P.M. and M.K.; visualization, K.S. and M.D.; supervision, M.D.-K.; project administration, B.K.; funding acquisition, J.M. and B.K. All authors have read and agreed to the published version of the manuscript.

Funding: This research received no external funding.

Institutional Review Board Statement: The study was conducted according to the guidelines of the Declaration of Helsinki, and approved by the Ethics Committee of Poznan University of Medical Sciences (resolution no. 344/19, 2019).

Informed Consent Statement: Not applicable.

Data Availability Statement: The data presented in this study are available on request from the corresponding author.

Acknowledgments: We would like to acknowledge Lasotronix Ltd. (Poland) for providing the SMARTm multi-wavelength laser.

Conflicts of Interest: The authors declare no conflict of interest. 


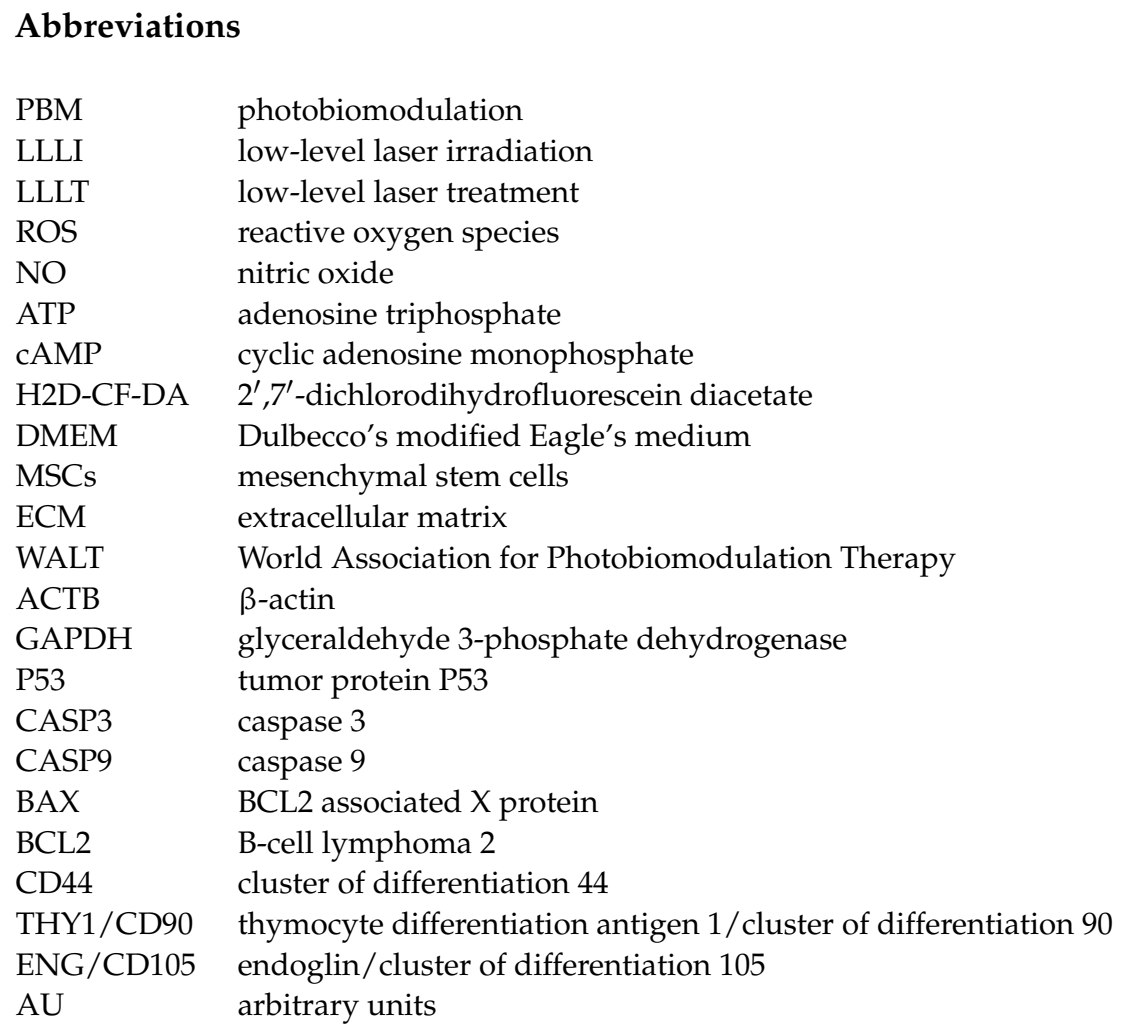

\section{References}

1. Sobouti, F.; Khatami, M.; Heydari, M.; Barati, M. The Role of Low-Level Laser in Periodontal Surgeries. J. Lasers Med. Sci. 2015, 6, 45-50. [CrossRef]

2. Goldman, L.; Hornby, P.; Meyer, R.; Goldman, B. Impact of the Laser on Dental Caries. Nature 1964, 203, 417. [CrossRef]

3. Stübinger, S. Advances in bone surgery: The Er:YAG laser in oral surgery and implant dentistry. Clin. Cosmet. Investig. Dent. 2010, 2, 47-62. [CrossRef]

4. Cobb, C.M.; Low, S.B.; Coluzzi, D.J. Lasers and the Treatment of Chronic Periodontitis. Dent. Clin. N. Am. 2010, 54, 35-53. [CrossRef]

5. Bjordal, J.M.; Johnson, M.I.; Iversen, V.; Aimbire, F.; Lopes-Martins, R. Low-Level Laser Therapy in Acute Pain: A Systematic Review of Possible Mechanisms of Action and Clinical Effects in Randomized Placebo-Controlled Trials. Photomed. Laser Surg. 2006, 24, 158-168. [CrossRef] [PubMed]

6. Almeida, A.L.; Esper, L.A.; Sbrana, M.C.; Ribeiro, I.W.; Kaizer, R.O. Utilization of Low-Intensity Laser During Healing of Free Gingival Grafts. Photomed. Laser Surg. 2009, 27, 561-564. [CrossRef] [PubMed]

7. Dompe, C.; Moncrieff, L.; Matys, J.; Grzech-Leśniak, K.; Kocherova, I.; Bryja, A.; Bruska, M.; Dominiak, M.; Mozdziak, P.; Skiba T.H.I.; et al. Photobiomodulation-Underlying Mechanism and Clinical Applications. J. Clin. Med. 2020, 9, 1724. [CrossRef] [PubMed]

8. Grzech-Leśniak, K.; Nowicka, J.; Pajączkowska, M.; Matys, J.; Szymonowicz, M.; Kuropka, P.; Rybak, Z.; Dobrzyński, M.; Dominiak, M. Effects of Nd:YAG laser irradiation on the growth of Candida albicans and Streptococcus mutans: In vitro study. Lasers Med Sci. 2018, 34, 129-137. [CrossRef] [PubMed]

9. Amorim, J.C.F.; De Sousa, G.R.; Silveira, L.D.B.; Prates, R.; Pinotti, M.; Ribeiro, M. Clinical Study of the Gingiva Healing after Gingivectomy and Low-Level Laser Therapy. Photomed. Laser Surg. 2006, 24, 588-594. [CrossRef] [PubMed]

10. Ozcelik, O.; Haytac, M.C.; Kunin, A.; Seydaoglu, G. Improved wound healing by low-level laser irradiation after gingivectomy operations: A controlled clinical pilot study. J. Clin. Periodontol. 2008, 35, 250-254. [CrossRef]

11. Arunachalam, L.T.; Sudhakar, U.; Janarthanam, A.S.; Das, N.M. Effect of low level laser therapy on revascularization of free gingival graft using ultrasound Doppler flowmetry. J. Indian Soc. Periodontol. 2014, 18, 403-407. [CrossRef]

12. Makhlouf, M.; Dahaba, M.M.; Tunér, J.; Eissa, S.A.; Harhash, T.A.-H. Effect of Adjunctive Low Level Laser Therapy (LLLT) on Nonsurgical Treatment of Chronic Periodontitis. Photomed. Laser Surg. 2012, 30, 160-166. [CrossRef] [PubMed]

13. Grzech-Leśniak, K. Making Use of Lasers in Periodontal Treatment: A New Gold Standard? Photomed. Laser Surg. 2017, 35, 513-514. [CrossRef]

14. Kujawa, J.; Pasternak, K.; Zavodnik, I.; Irzmanski, R.; Wrobel, D.; Bryszewska, M.; Pasternak-Mnich, K. The effect of near-infrared MLS laser radiation on cell membrane structure and radical generation. Lasers Med. Sci. 2014, 29, 1663-1668. [CrossRef] 
15. Zamani, A.R.N.; Saberianpour, S.; Geranmayeh, M.H.; Bani, F.; Haghighi, L.; Rahbarghazi, R. Modulatory effect of photobiomodulation on stem cell epigenetic memory: A highlight on differentiation capacity. Lasers Med Sci. 2020, 35, $299-306$. [CrossRef]

16. George, S.; Hamblin, M.R.; Abrahamse, H. Effect of red light and near infrared laser on the generation of reactive oxygen species in primary dermal fibroblasts. J. Photochem. Photobiol. B Biol. 2018, 188, 60-68. [CrossRef]

17. Tuner, J.; Hode, L. The Laser Therapy Handbook: A Guide for Research Scientists, Doctors, Dentists, Veterinarians and Other Interested Parties within the Medical Field; Prima Books: Indianapolis, IN, USA, 2007.

18. Huang, Y.-Y.; Chen, A.C.-H.; Carroll, J.D.; Hamblin, M.R. Biphasic Dose Response in Low Level Light Therapy. Dose-Response 2009, 7, 358-383. [CrossRef] [PubMed]

19. Lai, S.; Zee, K.-Y.; Lai, M.K.; Corbet, E. Clinical and Radiographic Investigation of the Adjunctive Effects of a Low-Power He-Ne Laser in the Treatment of Moderate to Advanced Periodontal Disease: A Pilot Study. Photomed. Laser Surg. 2009, 27, $287-293$. [CrossRef]

20. Hakki, S.S.; Bozkurt, S.B. Effects of different setting of diode laser on the mRNA expression of growth factors and type I collagen of human gingival fibroblasts. Lasers Med. Sci. 2011, 27, 325-331. [CrossRef] [PubMed]

21. Calderín, S.; García-Nuñez, J.A.; Gómez, C. Short-term clinical and osteoimmunological effects of scaling and root planing complemented by simple or repeated laser phototherapy in chronic periodontitis. Lasers Med. Sci. 2012, 28, 157-166. [CrossRef] [PubMed]

22. Aykol, G.; Baser, U.; Maden, I.; Kazak, Z.; Onan, U.; Tanrikulu-Kucuk, S.; Ademoglu, E.; Issever, H.; Yalcin, F. The Effect of Low-Level Laser Therapy as an Adjunct to Non-Surgical Periodontal Treatment. J. Periodontol. 2011, 82, 481-488. [CrossRef] [PubMed]

23. Ren, C.; McGrath, C.; Jin, L.; Zhang, C.; Yang, Y. The effectiveness of low-level laser therapy as an adjunct to non-surgical periodontal treatment: A meta-analysis. J. Periodontal Res. 2017, 52, 8-20. [CrossRef] [PubMed]

24. Alghamdi, K.M.; Kumar, A.; Moussa, N.A. Low-level laser therapy: A useful technique for enhancing the proliferation of various cultured cells. Lasers Med. Sci. 2011, 27, 237-249. [CrossRef]

25. Schindl, A.; Schindl, M.; Pernerstorfer-Schön, H.; Schindl, L. Low-intensity laser therapy: A review. J. Investig. Med. 2000, 48, 312-326. [PubMed]

26. Choi, E.-J.; Yim, J.-Y.; Koo, K.-T.; Seol, Y.-J.; Lee, Y.-M.; Ku, Y.; Rhyu, I.-C.; Chung, C.-P.; Kim, T.-I. Biological effects of a semiconductor diode laser on human periodontal ligament fibroblasts. J. Periodontal Implant. Sci. 2010, 40, 105-110. [CrossRef] [PubMed]

27. Almeida-Lopes, L.; Rigau, J.; Zângaro, R.A.; Guidugli-Neto, J.; Marques Jaeger, M.M. Comparison of the low level laser therapy effects on cultured human gingival fibroblasts proliferation using different irradiance and same fluence*. Lasers Surg. Med. 2001, 29, 179-184. [CrossRef]

28. WALT Dosage Recommendations. Available online: https://waltza.co.za/documentation-links/recommendations/dosagerecommendations / (accessed on 24 May 2021).

29. Chomczynski, P.; Sacchi, N. Single-step method of RNA isolation by acid guanidinium thiocyanate-phenol-chloroform extraction. Anal. Biochem. 1987, 162, 156-159. [CrossRef]

30. Kocherova, I.; Stefańska, K.; Bryl, R.; Perek, J.; Pieńkowski, W.; Zakova, J.; Crha, I.; Ventruba, P.; Mozdziak, P.; Ješeta, M. Apoptosis-related genes expression in primary in vitro culture of human ovarian granulosa cells. Med. J. Cell Biol. 2020, 8, 176-182. [CrossRef]

31. Livak, K.J.; Schmittgen, T.D. Analysis of relative gene expression data using real-time quantitative PCR and the $2^{-\Delta \Delta C T}$ method. Methods 2001, 25, 402-408. [CrossRef]

32. Bao, K.; Akgül, B.; Bostanci, N. Establishment and Characterization of Immortalized Gingival Epithelial and Fibroblastic Cell Lines for the Development of Organotypic Cultures. Cells Tissues Organs 2014, 199, 228-237. [CrossRef]

33. Sterczała, B.; Grzech-Leśniak, K.; Michel, O.; Trzeciakowski, W.; Dominiak, M.; Jurczyszyn, K. Assessment of Human Gingival Fibroblast Proliferation after Laser Stimulation In Vitro Using Different Laser Types and Wavelengths (1064, 980, 635, 450, and 405 nm)—Preliminary Report. J. Pers. Med. 2021, 11, 98. [CrossRef]

34. Papadelli, A.; Kyriakidou, K.; Kotsakis, G.A.; Pepelassi, E.; Kallis, A.; Vrotsos, I.A.; Karoussis, I.K. Immunomodulatory effects of Nd:YAG $(1064 \mathrm{~nm})$ and diode laser $(810 \mathrm{~nm})$ wavelengths to LPS-challenged human gingival fibroblasts. Arch. Oral Biol. 2021, 122, 104982. [CrossRef]

35. Frozanfar, A.; Ramezani, M.; Rahpeyma, A.; Khajehahmadi, S.; Arbab, H.R. The effects of low level laser therapy on the expression of collagen type I gene and proliferation of human gingival fibroblasts (HGF3-PI 53): In vitro study. Iran. J. Basic Med. Sci. 2013, 16, 1071-1074. [CrossRef] [PubMed]

36. Pereira, A.N.; De Paula Eduardo, C.; Matson, E. Effect of low-power laser irradiation on cell growth and procollagen synthesis of cultured fibroblasts. Lasers Surg. Med. 2002, 31, 263-267. [CrossRef]

37. Etemadi, A.; Namin, S.T.; Hodjat, M.; Kosarieh, E.; Hakimiha, N. Assessment of the Photobiomodulation Effect of a Blue Diode Laser on the Proliferation and Migration of Cultured Human Gingival Fibroblast Cells: A Preliminary In Vitro Study. J. Lasers Med. Sci. 2020, 11, 491-496. [CrossRef]

38. Reza Talebi-Ardakani, M.; Torshabi, M.; Karami, E.; Arbabi, E.; Rezaei Esfahrood, Z. In Vitro Study of Er:YAG and Er, Cr:YSGG Laser Irradiation on Human Gingival Fibroblast Cell Line. Acta Med. Iran. 2016, 54, 251-255. 
39. Ogita, M.; Tsuchida, S.; Aoki, A.; Satoh, M.; Kado, S.; Sawabe, M.; Nanbara, H.; Kobayashi, H.; Takeuchi, Y.; Mizutani, K.; et al. Increased cell proliferation and differential protein expression induced by low-level Er:YAG laser irradiation in human gingival fibroblasts: Proteomic analysis. Lasers Med. Sci. 2014, 30, 1855-1866. [CrossRef] [PubMed]

40. Kong, S.; Aoki, A.; Iwasaki, K.; Mizutani, K.; Katagiri, S.; Suda, T.; Ichinose, S.; Ogita, M.; Pavlic, V.; Izumi, Y. Biological effects of Er:YAG laser irradiation on the proliferation of primary human gingival fibroblasts. J. Biophotonics 2018, 11, e201700157. [CrossRef]

41. Ren, C.; McGrath, C.; Jin, L.; Zhang, C.; Yang, Y. Effect of diode low-level lasers on fibroblasts derived from human periodontal tissue: A systematic review of in vitro studies. Lasers Med. Sci. 2016, 31, 1493-1510. [CrossRef]

42. Ladiz, M.A.R.; Mirzaei, A.; Hendi, S.S.; Najafi-Vosough, R.; Hooshyarfard, A.; Gholami, L. Effect of photobiomodulation with 810 and $940 \mathrm{~nm}$ diode lasers on human gingival fibroblasts. Dent. Med. Probl. 2020, 57, 369-376. [CrossRef]

43. Victor, E.C.; Goulardins, J.; Cardoso, V.O.; Silva, R.E.C.; Brugnera, A.; Bussadori, S.K.; Fernandes, K.P.S.; Mesquita-Ferrari, R.A. Effect of Photobiomodulation in Lipopolysaccharide-Treated Myoblasts. Photobiomodulation Photomed. Laser Surg. 2021, 39, 30-37. [CrossRef]

44. Courtois, E.; Bouleftour, W.; Guy, J.-B.; Louati, S.; Bensadoun, R.-J.; Rodriguez-Lafrasse, C.; Magné, N. Mechanisms of PhotoBioModulation (PBM) focused on oral mucositis prevention and treatment: A scoping review. BMC Oral Health 2021, $21,1-11$. [CrossRef]

45. Liu, C.; Mo, L.; Niu, Y.; Li, X.; Zhou, X.; Xu, X. The Role of Reactive Oxygen Species and Autophagy in Periodontitis and Their Potential Linkage. Front. Physiol. 2017, 8, 439. [CrossRef] [PubMed]

46. Karu, T.I.; Pyatibrat, L.V.; Afanasyeva, N.I. Cellular effects of low power laser therapy can be mediated by nitric oxide. Lasers Surg. Med. 2005, 36, 307-314. [CrossRef] [PubMed]

47. Karu, T.I.; Pyatibrat, L.V.; Afanasyeva, N.I. A novel mitochondrial signaling pathway activated by visible-to-near infrared radiation. Photochem. Photobiol. 2004, 80, 366-372. [CrossRef]

48. Kwon, H.; Lim, W.; Kim, J.; Jeon, S.; Kim, S.; Karna, S.; Cha, H.; Kim, O.; Choi, H. Effect of 635 nm irradiation on high glucose-boosted inflammatory responses in LPS-induced MC3T3-E1 cells. Lasers Med. Sci. 2012, 28, 717-724. [CrossRef]

49. Ohsugi, Y.; Niimi, H.; Shimohira, T.; Hatasa, M.; Katagiri, S. In Vitro Cytological Responses against Laser Photobiomodulation for Periodontal Regeneration. Int. J. Mol. Sci. 2020, 21, 9002. [CrossRef]

50. Hamblin, M.R. Mechanisms and applications of the anti-inflammatory effects of photobiomodulation. AIMS Biophys. 2017, 4, 337-361. [CrossRef] [PubMed]

51. Sabatini, F.; Petecchia, L.; Tavian, M.; De Villeroché, V.J.; A Rossi, G.; Brouty-Boyé, D. Human bronchial fibroblasts exhibit a mesenchymal stem cell phenotype and multilineage differentiating potentialities. Lab. Investig. 2005, 85, 962-971. [CrossRef] [PubMed]

52. Huang, H.-I.; Chen, S.-K.; Ling, Q.-D.; Chien, C.-C.; Liu, H.-T.; Chan, S.-H. Multilineage Differentiation Potential of Fibroblast-like Stromal Cells Derived from Human Skin. Tissue Eng. Part A 2010, 16, 1491-1501. [CrossRef] [PubMed]

53. Chandravanshi, B.; Bhonde, R. Reprogramming mouse embryo fibroblasts to functional islets without genetic manipulation. J. Cell. Physiol. 2018, 233, 1627-1637. [CrossRef] [PubMed]

54. Lorenz, K.; Sicker, M.; Schmelzer, E.; Rupf, T.; Salvetter, J.; Schulz-Siegmund, M.; Bader, A. Multilineage differentiation potential of human dermal skin-derived fibroblasts. Exp. Dermatol. 2008, 17, 925-932. [CrossRef]

55. Huang, H.-I.; Chen, S.-K.; Wang, R.Y.-L.; Shen, C.-R.; Cheng, Y.-C. Human foreskin fibroblast-like stromal cells can differentiate into functional hepatocytic cells. Cell Biol. Int. 2013, 37, 1308-1319. [CrossRef] [PubMed]

56. Ichim, T.E.; O'Heeron, P.; Kesari, S. Fibroblasts as a practical alternative to mesenchymal stem cells. J. Transl. Med. 2018, 16, 1-9. [CrossRef]

57. Moraes, D.A.; Sibov, T.T.; Pavon, L.F.; Alvim, P.Q.; Bonadio, R.S.; Da Silva, J.R.; Pic-Taylor, A.; Toledo, O.A.; Marti, L.C.; Azevedo, R.B.; et al. A reduction in CD90 (THY-1) expression results in increased differentiation of mesenchymal stromal cells. Stem Cell Res. Ther. 2016, 7, 1-14. [CrossRef] [PubMed]

58. Liu, X.; Wong, S.S.; Taype, C.A.; Kim, J.; Shentu, T.-P.; Espinoza, C.R.; Finley, J.C.; Bradley, J.E.; Head, B.P.; Patel, H.H.; et al. Thy-1 interaction with Fas in lipid rafts regulates fibroblast apoptosis and lung injury resolution. Lab. Investig. 2017, 97, 256-267. [CrossRef] [PubMed]

59. Mokoena, D.R.; Houreld, N.N.; Kumar, S.S.D.; Abrahamse, H. Photobiomodulation at 660 nm Stimulates Fibroblast Differentiation. Lasers Surg. Med. 2020, 52, 671-681. [CrossRef]

60. Aguado, T.; García, M.; García, A.; Ferrer-Mayorga, G.; Martínez-Santamaría, L.; Del Río, M.; Botella, L.-M.; Sanchez, T.A. Raloxifene and n-acetylcysteine Ameliorate TGF-Signalling in Fibroblasts from Patients with Recessive Dominant Epidermolysis Bullosa. Cells 2020, 9, 2108. [CrossRef]

61. Gerrits, T.; Zandbergen, M.; Wolterbeek, R.; Bruijn, J.A.; Baelde, H.J.; Scharpfenecker, M. Endoglin Promotes Myofibroblast Differentiation and Extracellular Matrix Production in Diabetic Nephropathy. Int. J. Mol. Sci. 2020, 21, 7713. [CrossRef]

62. Kato, M.; Placencio-Hickok, V.R.; Madhav, A.; Haldar, S.; Tripathi, M.; Billet, S.; Mishra, R.; Smith, B.; Rohena-Rivera, K.; Agarwal, P.; et al. Heterogeneous cancer-associated fibroblast population potentiates neuroendocrine differentiation and castrate resistance in a CD105-dependent manner. Oncogene 2018, 38, 716-730. [CrossRef]

63. Karic, V.; Chandran, R.; Abrahamse, H. Laser-Induced Differentiation of Human Adipose-Derived Stem Cells to Temporomandibular Joint Disc Cells. Lasers Surg. Med. 2021, 53, 567-577. [CrossRef] [PubMed]

64. Yang, R.; Guo, S.; Xiao, S.; Ding, Y. Enhanced wound healing and osteogenic potential of photodynamic therapy on human gingival fibroblasts. Photodiagnosis Photodyn. Ther. 2020, 32, 101967. [CrossRef] [PubMed] 